\title{
CAI 25, CEA, CAI9-9, and Heteroploid Cells in Ascites Fluid May Help Diagnose Peritoneal Carcinomatosis in Patients with Gastrointestinal and Ovarian Malignancies
}

This article was published in the following Dove Press journal:

Cancer Management and Research

\author{
Lin Deng ${ }^{1, *}$ \\ Shikong Guo ${ }^{2, *}$ \\ Hong $\mathrm{Li}^{\prime}$ \\ Xianghui You' \\ Yang Song' \\ Haichuan Su' \\ 'Department of Oncology, Tangdu \\ Hospital, Air Force Military Medical \\ University, Xi'an, Shaanxi, China; \\ ${ }^{2}$ Department of Orthopedics, Tangdu \\ Hospital, Air Force Military Medical \\ University, Xi'an, Shaanxi, China \\ *These authors contributed equally to \\ this work
}

Background: This study explored the value of ascites and serum CA125, CEA, and CA19-9 levels and ascites DNA ploidy analysis for the diagnosis of peritoneal carcinomatosis (PC) in patients with gastrointestinal and ovarian malignancies, which can cause ascites and may disseminate peritoneally.

Methods: We measured ascites and serum levels of CA125, CEA, CA19-9 and performed an ascites DNA ploidy analysis in 58 patients with PC and 44 patients without PC.

Results: We found that a high expression level of CA125 in ascites fluid was associated with the occurrence of PC in patients with gastrointestinal and ovarian malignancies $(P<0.001)$, and that high CEA and CA19- 9 levels in ascites fluid were associated with PC in patients with gastrointestinal malignancies $(P=0.001, P=0.002)$. But, these tumor marker expression levels in ascites fluid were not significantly associated with the PC stage $(P>0.05)$. We found similar serum levels of CA125, CEA, and CA19-9 between patients with gastrointestinal and ovarian malignancies and PC and those without PC $(P>0.05)$. We found that the presence of three or more cells with heteroploid in the ascites samples was significantly associated with $\mathrm{PC}$ in gastrointestinal and ovarian malignancies $(P<0.001)$. In addition, the best ROC curves and highest AUCs were achieved by combining the CA125 level and heteroploid cell analysis results (AUC for gastrointestinal and ovarian malignancies, 0.815, AUC for gastrointestinal malignancies, 0.873). Moreover, the combined ascites CA125 level and result of heteroploid cell analysis provided the best diagnostic sensitivity and specificity for PC (75.9\% and $79.5 \%$, respectively, in gastrointestinal and ovarian malignancies; $85.0 \%$ and $86.7 \%$, respectively, in gastrointestinal malignancies).

Conclusion: Ascites levels of CA125, CEA, CA19-9, and heteroploid cells can be considered valuable markers for the diagnosis of $\mathrm{PC}$ in patients with gastrointestinal and ovarian cancer.

Keywords: peritoneal carcinomatosis, tumor marker, ascites, heteroploid cell

\section{Introduction}

Ascites can be caused by a variety of factors such as portal vein tumor thrombosis, malnutrition, peritonitis, vascular or lymphatic vascular invasion, and peritoneal carcinomatosis (PC) in patients with malignant tumors. ${ }^{1}$ Abdomen pelvic cavity cancer can easily induce the appearance of ascites. Gastrointestinal and ovarian malignancies have the potential to disseminate and grow in the peritoneal cavity, and peritoneal carcinomatosis is often associated with poor prognosis. ${ }^{2,3}$ Combined
Correspondence: Yang Song; Haichuan Su Email songyang212212@163.com; suhaic_I@I63.com 
therapy mainly composed of surgery should be adopted in patients with gastrointestinal cancer to improve the survival rate, but the occurrence of PC has been shown to signal the failure of surgical therapy. ${ }^{4}$ Furthermore, this condition is commonly observed in ovarian cancer, and $\mathrm{PC}$ of the tumor is the most common cause of death. ${ }^{5}$ Therefore, early PC diagnosis and treatment in patients with ascites are very important. At present, the gold standard for PC diagnosis is direct peritoneal visualization, either by laparotomy or laparoscopy combined with pathology. ${ }^{6}$ For patients with massive ascites who are not surgical candidates, imaging techniques (such as Computed Tomography or MRI) and the detection of tumor cells in ascites can be used to help diagnose PC. ${ }^{7,8}$ However, imaging examinations are limited in their ability to visualize localized PC, due to low sensitivity for small lesions. The detection rate of tumor cells in cases with massive ascites is low. Therefore, new methods to assist in diagnosing PC are needed.

Serum tumor markers are widely used for diagnosis, treatment effect assessment, and disease monitoring. ${ }^{9}$ However, few studies have explored the diagnostic value of tumor markers for PC in ascites fluid. Some researchers have argued that peritoneal fluid carcinoembryonic antigen (CEA) has predictive value for PC and prognostic value in colorectal cancer. ${ }^{10}$ The CEA is the most widely used tumor marker. The carbohydrate antigen 125 (CA125) is highly specific for gastrointestinal and ovarian malignancies, and the carbohydrate antigen 199 (CA19-9) is used particularly to diagnose gastrointestinal cancers. ${ }^{11}$ In this study, we detected the ascites and serum levels of CEA, CA125, and CA19-9 in patients with gastrointestinal and ovarian malignancies, which have the potential to disseminate in the peritoneum, to determine whether these levels are associated with the presence of PC.

Flow cytometry DNA ploidy analysis can analyze relatively small numbers of cells and provides general chromosomal/ploidy information in many diseases. DNA ploidy analysis can signal gross genomic aberrations and has been used to determine prognoses in pre-cancerous and cancerous lesions. ${ }^{12}$ According to some authors, DNA flow cytometric parameters have prognostic value in differentiating benign from malignant fluids in the serous membrane cavity. ${ }^{13}$ In this study, we explored whether DNA ploidy analysis of ascites fluid can assist in the diagnosis of PC.

\section{Patients and Methods}

\section{Patients}

A total of 102 patients with gastrointestinal and ovarian malignancy with moderate to severe ascites diagnosed and treated at the Tangdu Hospital of the Air Force Military Medical University from January 2016 to January 2020 participated in our study (38 with gastric cancer, 32 with colon cancer, and 32 with ovarian cancer). Among them, 58 patients were diagnosed as having PC, including 22 with gastric cancer, 18 with colon cancer patients, and 18 with ovarian cancer (20 patients diagnosis was confirmed by pathologic results, 38 patients had cancer cells detected in ascites fluid according to pathology results and imaging results); and 44 patients did not have $\mathrm{PC}$, including 16 with gastric cancer, 14 with colon cancer, and 14 with ovarian cancer. All patients had ascites volumes greater than $1500 \mathrm{~mL}$, as evaluated by ultrasound (we found no patients with hemorrhagic or chyliform ascites). To avoid possible effects of chemotherapy on the ascites and serum levels of CEA, CA19-9, and CA125, none of the selected patients had undergone chemotherapy in the month prior to the samplings. We used the Lyon staging system (Gilly PC) descriptions for quantifying PC divided into 5 stages from 0 to 4 and estimated based on imaging techniques (CT, MRI): Stage 0 , no macroscopic disease; stage 1, malignant granulations less than $5 \mathrm{~mm}$ in diameter in one part of the abdomen; stage 2, malignant granulations less than $5 \mathrm{~mm}$ in diameter diffuse throughout the abdomen; stage 3 , malignant granulations $5 \mathrm{~mm}$ to $2 \mathrm{~cm}$ in diameter; and stage 4 , large malignant cakes (more than $2 \mathrm{~cm}$ in diameter). ${ }^{14}$ Table 1 presents the detailed characteristics of the patients.

\section{Specimen Collection and Tumor Marker Assays}

Ascites samples were collected from patients with various conditions during diagnostic or therapeutic paracenteses. The fasting venous blood specimens of all patients for tumor marker detection were obtained through venipuncture. Ascites (approximately $5 \mathrm{~mL}$ ) and venous blood samples (approximately $3 \mathrm{~mL}$ ) were centrifuged for $10 \mathrm{~min}$ at $3000 \mathrm{rpm}$. The supernatants were stored in separate tubes at $-80^{\circ} \mathrm{C}$ for further analysis. CEA levels were investigated using a fluorescenceenzyme immunoassay (FEIA), while CA19-9 and CA125 levels were investigated using a chemiluminescent enzyme immunoassay (CLEIA); these assays were performed at the Department of Clinical Laboratory. Ascites (approximately $200 \mathrm{~mL}$ ) were taken to the pathology department for cytologic 
Table I Patient Characteristics

\begin{tabular}{|c|c|c|c|}
\hline Characteristics & $\begin{array}{l}\text { CRC } \\
(\mathrm{N}=32)\end{array}$ & $\begin{array}{l}G C \\
(N=38)\end{array}$ & $\begin{array}{l}O C \\
(N=32)\end{array}$ \\
\hline $\begin{array}{l}\text { Age (years) } \\
\text { Median } \\
\text { Range }\end{array}$ & $\begin{array}{l}57 \\
29-79\end{array}$ & $\begin{array}{l}59 \\
39-80\end{array}$ & $\begin{array}{l}55 \\
37-75\end{array}$ \\
\hline $\begin{array}{l}\text { Gender, } n(\%) \\
\text { Male } \\
\text { Female }\end{array}$ & $\begin{array}{l}19(59.4) \\
13(40.6)\end{array}$ & $\begin{array}{l}24(63.2) \\
14(36.8)\end{array}$ & $\begin{array}{l}0(0) \\
32(100.0)\end{array}$ \\
\hline Performance status & & & \\
\hline $\begin{array}{l}\text { (ECOG), n(\%) } \\
1 \\
2 \\
3\end{array}$ & $\begin{array}{l}7(21.8) \\
15(46.9) \\
10(31.3)\end{array}$ & $\begin{array}{l}13(34.2) \\
21(55.3) \\
4(10.5)\end{array}$ & $\begin{array}{l}12(37.5) \\
16(50.0) \\
4(12.5)\end{array}$ \\
\hline $\begin{array}{l}\text { Tumor histology, n(\%) } \\
\text { Adenocarcinoma } \\
\text { Serous } \\
\text { Mucinous }\end{array}$ & $\begin{array}{l}32(100.0) \\
- \\
-\end{array}$ & $\begin{array}{l}38(100.0) \\
- \\
-\end{array}$ & $\begin{array}{l}- \\
22(81.3) \\
10(18.7)\end{array}$ \\
\hline $\begin{array}{l}\text { Tumor site, } \mathrm{n}(\%) \\
\text { Right } \\
\text { Left }\end{array}$ & $\begin{array}{l}17(53.1) \\
15(46.9)\end{array}$ & $\begin{array}{l}- \\
-\end{array}$ & $\begin{array}{l}- \\
-\end{array}$ \\
\hline $\begin{array}{l}\text { Tumor stage (TNM), n(\%) } \\
\text { III } \\
\text { IV }\end{array}$ & $\begin{array}{l}11(34.4) \\
21(65.6)\end{array}$ & $\begin{array}{l}12(31.6) \\
26(68.4)\end{array}$ & $\begin{array}{l}16(50.0) \\
16(50.0)\end{array}$ \\
\hline $\begin{array}{l}\text { Histologic differentiation } \\
\text { Well } \\
\text { Moderate } \\
\text { Poor }\end{array}$ & $\begin{array}{l}5(15.6) \\
17(53.1) \\
10(31.3)\end{array}$ & $\begin{array}{l}4(10.6) \\
17(44.7) \\
17(44.7)\end{array}$ & $\begin{array}{l}4(12.5) \\
18(56.3) \\
10(31.2)\end{array}$ \\
\hline $\begin{array}{l}\text { Peritoneal metastasis, } \mathrm{n}(\%) \\
\text { Positive } \\
\text { Negative }\end{array}$ & $\begin{array}{l}18(56.3) \\
14(43.7)\end{array}$ & $\begin{array}{l}22(57.9) \\
16(42.1)\end{array}$ & $\begin{array}{l}18(56.3) \\
14(43.7)\end{array}$ \\
\hline $\begin{array}{l}\text { Liver metastasis, } \mathrm{n}(\%) \\
\text { Positive } \\
\text { Negative }\end{array}$ & $\begin{array}{l}16(50.0) \\
16(50.0)\end{array}$ & $\begin{array}{l}17(44.7) \\
21(55.3)\end{array}$ & $\begin{array}{l}7(21.9) \\
25(78.1)\end{array}$ \\
\hline $\begin{array}{l}\text { Ascites volume, } \mathrm{n}(\%) \\
\text { I500-3000mL } \\
\text { over } 3000 \mathrm{~mL}\end{array}$ & $\begin{array}{l}13(40.6) \\
19(59.4)\end{array}$ & $\begin{array}{l}19(50.0) \\
19(50.0)\end{array}$ & $\begin{array}{l}14(43.8) \\
18(56.2)\end{array}$ \\
\hline $\begin{array}{l}\text { Diagnosis method of } \mathrm{PC} \\
(\mathrm{N}=58), \mathrm{n}(\%) \\
\text { Pathological diagnosis } \\
\mathrm{CT} \text { and tumor cell in ascites } \\
\text { MRI and tumor cell in ascites }\end{array}$ & $\begin{array}{l}5(27.8) \\
9(50.0) \\
4(22.2)\end{array}$ & $\begin{array}{l}8(36.4) \\
14(63.6) \\
0(0)\end{array}$ & $\begin{array}{l}7(38.9) \\
6(33.3) \\
5(27.8)\end{array}$ \\
\hline $\begin{array}{l}\text { Gilly PC (N=58), n(\%) } \\
\quad \begin{array}{l}1 \\
2 \\
3 \\
4\end{array}\end{array}$ & $\begin{array}{l}6(33.3) \\
4(22.2) \\
7(38.9) \\
1(5.6)\end{array}$ & $\begin{array}{l}4(18.2) \\
4(18.2) \\
10(45.4) \\
4(18.2)\end{array}$ & $\begin{array}{l}2(11.1) \\
4(22.2) \\
7(38.9) \\
5(27.8)\end{array}$ \\
\hline
\end{tabular}

(Continued)
Table I (Continued).

\begin{tabular}{|l|l|l|l|}
\hline Characteristics & $\begin{array}{l}\text { CRC } \\
\mathbf{( N = 3 2 )}\end{array}$ & $\begin{array}{l}\text { GC } \\
\mathbf{( N = 3 8 )}\end{array}$ & $\begin{array}{l}\text { OC } \\
\mathbf{( N = 3 2 )}\end{array}$ \\
\hline Treatment received & & & \\
\hline $\begin{array}{l}\text { Prior chemotherapy, n(\%) } \\
\text { Yes }\end{array}$ & $16(50.0)$ & $24(63.2)$ & $1 \mathrm{I}(34.4)$ \\
No & $16(50.0)$ & $14(36.8)$ & $21(65.6)$ \\
\hline $\begin{array}{l}\text { Prior surgery, n(\%) } \\
\text { Yes }\end{array}$ & $15(46.9)$ & $26(68.4)$ & $12(37.5)$ \\
No & $17(53.1)$ & $12(31.6)$ & $20(62.5)$ \\
\hline
\end{tabular}

Abbreviations: CRC, colorectal cancer; GC, gastric cancer; OC, ovarian cancer.

evaluation and DNA ploidy analysis. The peritoneal biopsy, serum collection and paracentesis were done the same week with CT/MRI scans, and there is no change in the tumor stage during this time. The institutional review board (IRB) at Tangdu Hospital, approved this study, and we obtained a prior written informed consent from every patient.

\section{Cell Cycle Analysis and Ploidy Analysis}

DNA ploidy analysis was performed using a flow cytometer. After fixing $150 \mu \mathrm{L}$ ascites samples with $70 \%$ alcohol, they were stained with propidium iodide $(50 \mu \mathrm{g} / \mathrm{mL}$, Sigma, St. Louis, Missouri, USA). Nuclear DNA was measured in a flow cytometer. Usually, 10,000 nuclei were counted and DNA ploidy was expressed by the DI. The DI was calculated according to the principles recommended by consensus: DI represents the ratio of the aneuploid G1-G0-DNA peak channel to the diploid G1-G0-DNA peak channel. For this series, we classified populations with $1.0<\mathrm{DI}<1.2$ as near-diploid cases and separated them from DNA aneuploid tumors. We analyzed DNA ploidy in 102 patient samples. Among them, 18 lacked cells with DNA heteroploidy, 27 had 1 to 2 cells with heteroploidy, and 57 had three or more cells with heteroploidy.

\section{Statistical Analysis}

We used the Statistical Package for Social Sciences (SPSS ${ }^{\circledR}$, IBM) version 20 software for statistical data analyses. All values are expressed as medians (minimum-maximum). After the homogeneity test, we used nonparametric tests (Mann-Whitney $U$-test, Kruskal-Wallis $H$-test) for statistical evaluation. We evaluated a difference between positive rates by the Chi-square test. We plotted receiver operating characteristic (ROC) curves and calculated the areas under the curve (AUC). We applied ROC curve and Youden index 
analyses to calculate the optimal cut-off values for ascites tumor markers. For all analysis, $P$ values $<0.05$ indicated statistical significance.

\section{Results}

\section{Elevated CAI 25 Levels in Ascites Fluid} Were Associated with the Incidence of PC in Patients with Gastrointestinal and Ovarian Cancer

In patients with gastrointestinal and ovarian cancer, the expression level of CA125 in ascites fluid was associated with the presence of PC $(P<0.001)$, but it did not correlate with the tumor stage, histologic differentiation, or liver metastasis $(P>0.05)$. However, we found similar serum levels of CEA, CA19-9, and CA125 between patients with $\mathrm{PC}$ and without PC $(P=0.88, P=0.82$, and $P=0.22$, respectively) (Table 2). Our results show that ascites fluid CA125 levels may help during PC screening in patients with gastrointestinal and ovarian cancer and ascites. For this study, we calculated the ascites volume of patients by ultrasound and categorized them into 2 groups: $1500 \mathrm{~mL}$ to $3000 \mathrm{~mL}$ and > $3000 \mathrm{~mL}$. The CA125 level in ascites fluid was associated with the volume of ascites $(P=0.04)$ (Table 2$)$.

\section{Elevated CEA and CA19-9 Levels in} Ascites Fluid Were Associated with the Incidence of PC in Patients with

\section{Gastrointestinal Cancer}

CEA and CA19-9 are more specific tumor markers for gastrointestinal cancer than for ovarian cancer. Through our clinical data analysis, we found that increased ascites CEA and CA19-9 levels in patients with gastrointestinal cancer and $\mathrm{PC}$ may be meaningful ( $P=0.001, P=0.002$, respectively). But, ascites CEA and CA19-9 levels were not correlated with tumor stage, histologic differentiation, ascites volume, or liver metastasis $(P>0.05)$. We found similar serum levels of CEA and CA19-9 between patients with PC and without PC ( $P=0.19, P=0.08$, respectively) (Table 3$)$.

\section{Association Between Ascites CEA, CA 19-9, and CAI 25 Levels and PC Stage in Patients with Gastrointestinal and Ovarian Cancer}

In our previous research, we considered that the expression levels of CEA, CA19-9, and CA125 in ascites were associated with the occurrence of PC. We used the Lyon staging system (Gilly PC) descriptions for quantifying PC into 5 grades from 0 to 4 as estimated using imaging techniques (CT, MRI). However, we found no correlation between ascites tumor marker levels and the Gilly PC stage $(P>0.05)$ (Table 4$)$.

\section{Significance of Ascites DNA Ploidy Analysis in Diagnosis of PC}

We analyzed DNA ploidy in 102 patients. We defined ascites samples with three or more heteroploid cells as positive, and those without DNA heteroploidy or with only 1 to 2 heteroploid cells as negative. We found that the heteroploid positivity was significantly associated with the presence of $\mathrm{PC}$ in patients with gastrointestinal and ovarian cancer $(P<0.001)$ (Table 5$)$.

\section{Receiver Operating Characteristic (ROC) Curve Analysis and Evaluation of the Sensitivity and Specificity of Each of the Tumor Markers for PC Diagnosis}

To better assess the diagnostic value of tumor makers and DNA ploidy analysis to detect PC, we plotted ROC curves and calculated AUCs. The results of DNA ploidy analysis were divided into three grades: absence of cells with DNA heteroploidy; 1 to 2 cells with heteroploidy; and 3 or more cells with heteroploidy.

In patients with gastrointestinal and ovarian cancer, the best ROC curves and highest AUC were achieved using a combination of the CA125 level and the heteroploid cell analysis results (AUC, 0.815), followed by using the CA125 level alone (AUC, 0.732). The lowest AUC was achieved using the heteroploid cell analysis results (AUC, 0.703). The cutoff for CA125 was $549.4 \mathrm{U} / \mathrm{mL}$ (Figure 1, Table 6). When using two indicators for PC diagnosis, the best sensitivity (75.9\%) and specificity (79.5\%) were shown when combining the CA125 level and the heteroploid cell analysis result. The highest Youden's index also was obtained with the CA125 level and heteroploid cell analysis result combination at $55.4 \%$ (Table 7).

In patients with gastrointestinal cancer, the best ROC curves and highest AUC were achieved using the heteroploid cell analysis results (AUC, 0.760), followed by the CA125 level (AUC, 0.742), and the CEA level (AUC, 0.723). The lowest AUC was achieved using the CA19-9 level (AUC, 0.718). The cutoff levels of CA125, CEA, and CA19-9 were $528.8 \mathrm{U} / \mathrm{mL}, 211.9 \mathrm{ng} / \mathrm{mL}$, and $283.0 \mathrm{U} / \mathrm{mL}$, 


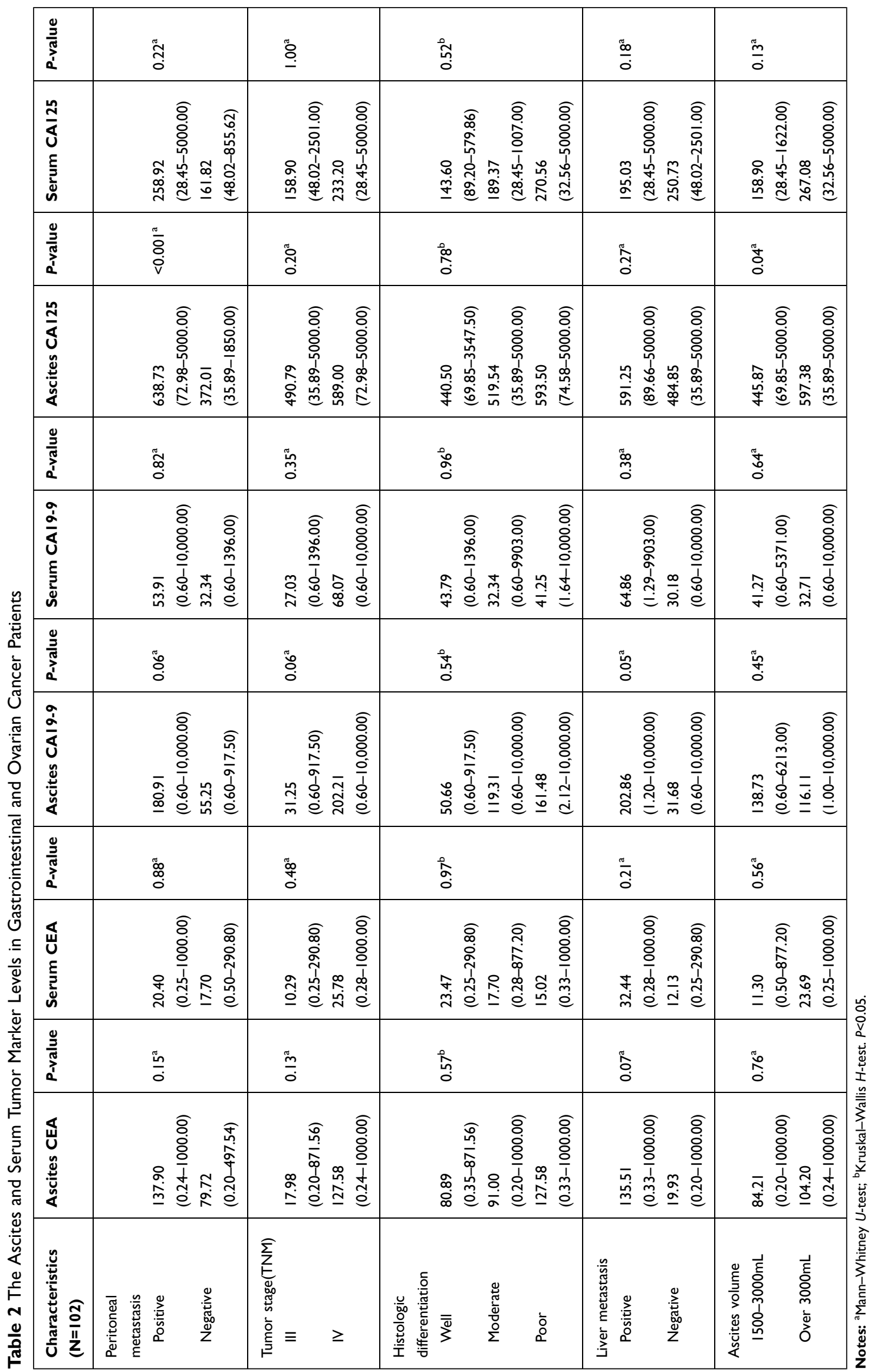




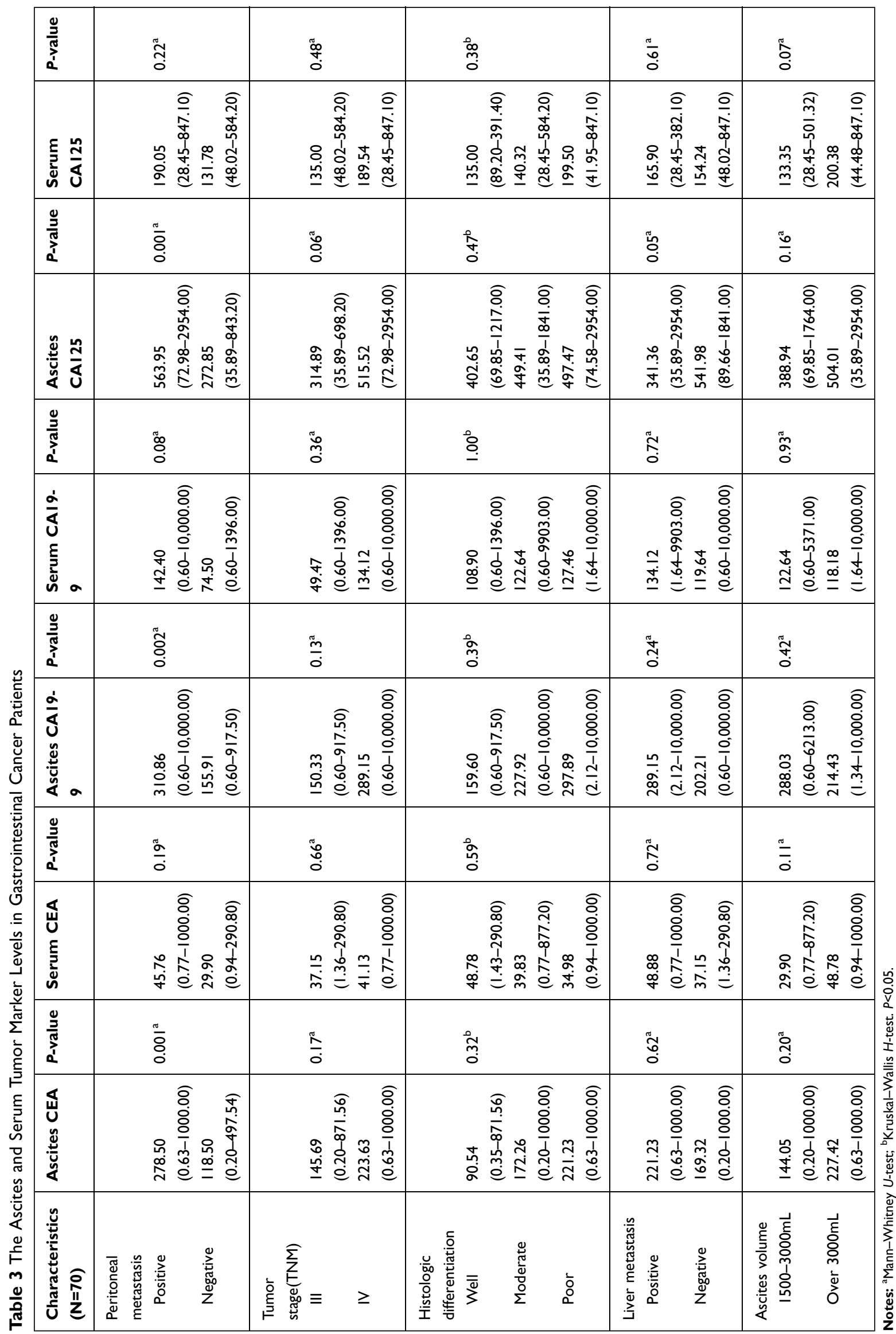


Table 4 Association of Ascites Tumor Marker Levels with Gilly PC Stage in Gastrointestinal and Ovarian Cancer Patients

\begin{tabular}{|c|c|c|c|}
\hline \multirow[t]{2}{*}{ Category } & \multicolumn{2}{|l|}{ Gilly PC Stage } & \multirow[t]{2}{*}{$P$-value ${ }^{a}$} \\
\hline & Stage $0-2$ & Stage 3-4 & \\
\hline \multicolumn{4}{|c|}{ In gastrointestinal and ovarian cancer patients $(\mathrm{N}=58)$} \\
\hline $\mathrm{CA} / 25$ & $\begin{array}{l}556.78 \\
(87.65-5000.00)\end{array}$ & $\begin{array}{l}850.65 \\
(72.98-5000.00)\end{array}$ & 0.08 \\
\hline \multicolumn{4}{|c|}{ In gastrointestinal cancer patients $(\mathrm{N}=40)$} \\
\hline CEA & $\begin{array}{l}278.50 \\
(0.63-1000.00)\end{array}$ & $\begin{array}{l}231.40 \\
(0.71-1000.00)\end{array}$ & 0.74 \\
\hline CAI9-9 & $\begin{array}{l}289.15 \\
(2.12-10,000.00)\end{array}$ & $\begin{array}{l}378.35 \\
(0.60-10,000.00)\end{array}$ & 0.70 \\
\hline
\end{tabular}

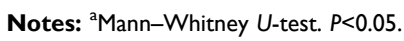

Table 5 Comparison of Positive Rates of Heteroploid Cells in the Two Groups

\begin{tabular}{|c|c|c|c|c|}
\hline \multirow[t]{2}{*}{ Category } & \multicolumn{2}{|c|}{ Peritoneal Metastasis } & \multirow[t]{2}{*}{$x^{2}$} & \multirow[t]{2}{*}{$P$-value ${ }^{a}$} \\
\hline & $\begin{array}{l}\text { Positive } \\
\text { (n, \%) }\end{array}$ & $\begin{array}{l}\text { Negative } \\
(n, \%)\end{array}$ & & \\
\hline \multicolumn{5}{|c|}{ In gastrointestinal and ovarian cancer patients $(\mathrm{N}=102)$} \\
\hline $\begin{array}{l}\text { Positive } \\
\text { Negative }\end{array}$ & $\begin{array}{l}43(42.2) \\
15(14.7)\end{array}$ & $\begin{array}{l}14(13.7) \\
30(29.4)\end{array}$ & 18.18 & $<0.001$ \\
\hline \multicolumn{5}{|c|}{ In gastrointestinal cancer patients $(\mathrm{N}=70)$} \\
\hline $\begin{array}{l}\text { Positive } \\
\text { Negative }\end{array}$ & $\begin{array}{l}3 \mid(44.3) \\
9(\mid 2.9)\end{array}$ & $\begin{array}{l}7(10.0) \\
23(32.8)\end{array}$ & 20.27 & $<0.001$ \\
\hline
\end{tabular}

Notes: ${ }^{a}$ Chi-square test. $P<0.05$.

respectively. When two indicators were combined, the largest AUC was obtained using the CA125 level and the heteroploid cell analysis result (AUC, 0.873), while the smallest AUC was obtained using the CEA and CA199 levels (AUC, 0.788) (Figure 2, Table 8). When using one indicator for PC diagnosis, the best sensitivity was shown by the heteroploid cell analysis result at $77.5 \%$, and the best specificity by the CA125 level at $86.6 \%$. We obtained the highest Youden's index using the heteroploid cell analysis result (54.2\%) and the lowest using the CA125 level (41.7\%). The combined use of the CA125 level and the heteroploid cell analysis result led to the highest sensitivity $(85.0 \%)$ and specificity $(86.7 \%)$ for two PC indicators. We also obtained the highest Youden's index (71.7\%) after using the same PC indicators' combination, and we obtained the lowest Youden's index (52.5\%) after using the combination between the CA125 and CEA levels (Table 9).

\section{Discussion}

Abdomen pelvic cavity cancers, such as gastrointestinal and ovarian cancers, can easily induce the appearance of ascites, and they also can disseminate and grow in the peritoneal cavity. ${ }^{15}$ Ascites is a common complication of advanced stage cancers with PC. ${ }^{16}$ Therefore, the appearance of ascites in patients with advanced tumors is associated with an increased risk of PC. Moreover, the appearance of $\mathrm{PC}$ is often associated with a poor prognosis. Early PC diagnosis and prompt treatment can prolong the survival of patients. Although the gold standard for PC diagnosis is a pathology result, collecting biopsy tissues from the peritoneum of patients with massive ascites is difficult. Imaging techniques (such as CT or MRI) and the detection of tumor cells in ascites can be used to help diagnose PC, but imaging examinations are limited by their low sensitivity for small lesions, and the detection rate of tumor cells in cases with massive ascites is low. Therefore, new methods to assist in diagnosing PC are needed.

Recently, Kim showed that the ascites CEA level is a risk factor for PC in patients with colorectal cancer. ${ }^{10}$ This suggests that ascites tumor markers may be clinically useful markers for PC diagnoses. Clinical experience indicates that the presence of malignant cells in ascites fluid is associated with an increase in the risk of PC. Some researchers have argued that the prognosis of patients with gastric cancer and malignant ascites is associated with the presence of PC. ${ }^{17,18}$ Although cytomorphology remains the foremost diagnostic modality to detect malignant cells in effusions, DNA flow cytometry can detect heteroploid cells and has a complementary value. ${ }^{19}$ A previous report stated that ascites tumor markers and heteroploid cell analysis results exhibit an excellent diagnostic performance for diagnosing malignant ascites. ${ }^{20-23}$ In this study, we explored whether ascites tumor markers and heteroploid cell analysis results can assist in diagnosing PC.

We analyzed the diagnostic value of ascites and serum tumor marker levels and heteroploid cell analysis results in ascites fluid for PC in 102 patients with gastrointestinal and ovarian cancer and moderate to severe ascites; we found 58 patients with $\mathrm{PC}$ and 44 without it. Our results indicate that an elevated ascites CA125 level was associated with the incidence of PC in patients with gastrointestinal and ovarian cancer $(P<0.001)$. The CA125 level in ascites fluid was significantly associated with the 


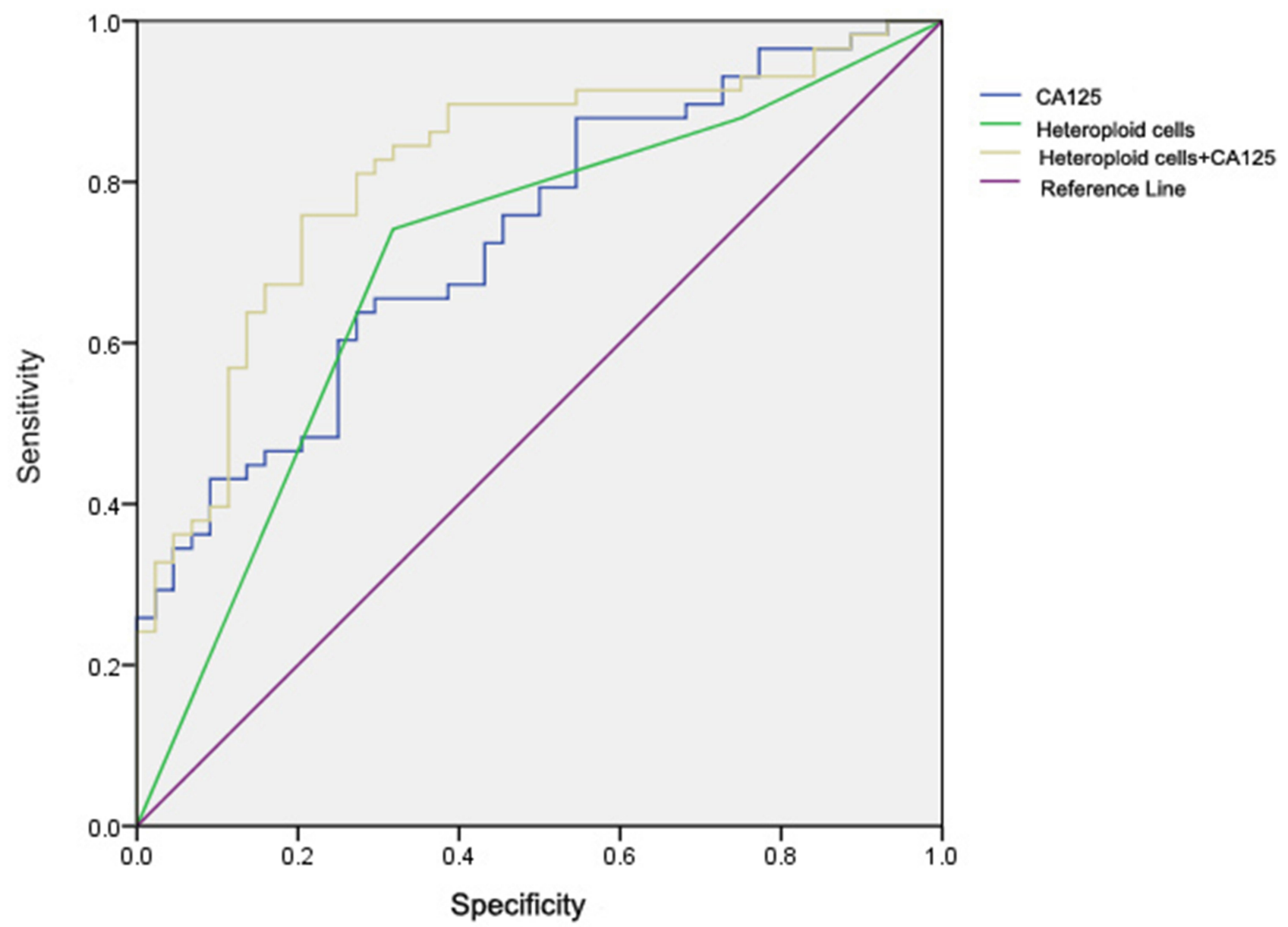

Figure I ROC of tumor markers and heteroploid cells in the diagnosis of PC in gastrointestinal and ovarian cancer patients.

volume of ascites $(P<0.05)$. In addition, elevated ascites CEA and CA19-9 levels were associated with peritoneal dissemination in gastrointestinal cancers $(P<0.05)$. However, we found similar serum levels of CEA, CA199, and CA125 between patients with PC and those without PC $(P>0.05)$. Further, we found no correlation between ascites tumor marker levels and Gilly PC stages $(P>0.05)$. Furthermore, we found that the presence of 3 or more cells with heteroploidy in ascites samples was significantly

Table 6 The Area of ROC of Ascites Tumor Markers and Heteroploid Cells in Gastrointestinal and Ovarian Cancer Patients

\begin{tabular}{|l|l|l|l|}
\hline Category & Area & $\mathbf{P}$ & $\mathbf{9 5 \%} \mathbf{C l}$ \\
\hline CAI25 & 0.732 & $<0.001$ & $0.637-0.828$ \\
Heteroploid cells & 0.703 & $<0.001$ & $0.598-0.807$ \\
CAI25+Heteroploid cells & 0.815 & $<0.001$ & $0.730-0.899$ \\
\hline
\end{tabular}

associated with the presence of PC in patients with gastrointestinal and ovarian cancer $(P<0.001)$.

Our data suggest that ascites CEA, CA19-9, and CA125 levels and the quantity of heteroploid cells may be helpful for diagnosing $\mathrm{PC}$ in patients with gastrointestinal and ovarian cancer with ascites. However, the sensitivity was low when using a single indicator to diagnosis PC, making it impractical during clinical diagnoses. However, we found that using a combination of two

Table 7 Tumor Markers and Heteroploid Cells in the Diagnosis of PC in Gastrointestinal and Ovarian Cancer Patients

\begin{tabular}{|l|l|l|l|}
\hline Category & $\begin{array}{l}\text { Sensitivity } \\
\text { (\%) }\end{array}$ & $\begin{array}{l}\text { Specificity } \\
\text { (\%) }\end{array}$ & $\begin{array}{l}\text { Youden's } \\
\text { Index (\%) }\end{array}$ \\
\hline CAI25 & 63.8 & 72.7 & 36.5 \\
Heteroploid cells & 74.1 & 68.2 & 42.3 \\
CAI25 & 75.9 & 79.5 & 55.4 \\
+Heteroploid cells & & & \\
\hline
\end{tabular}




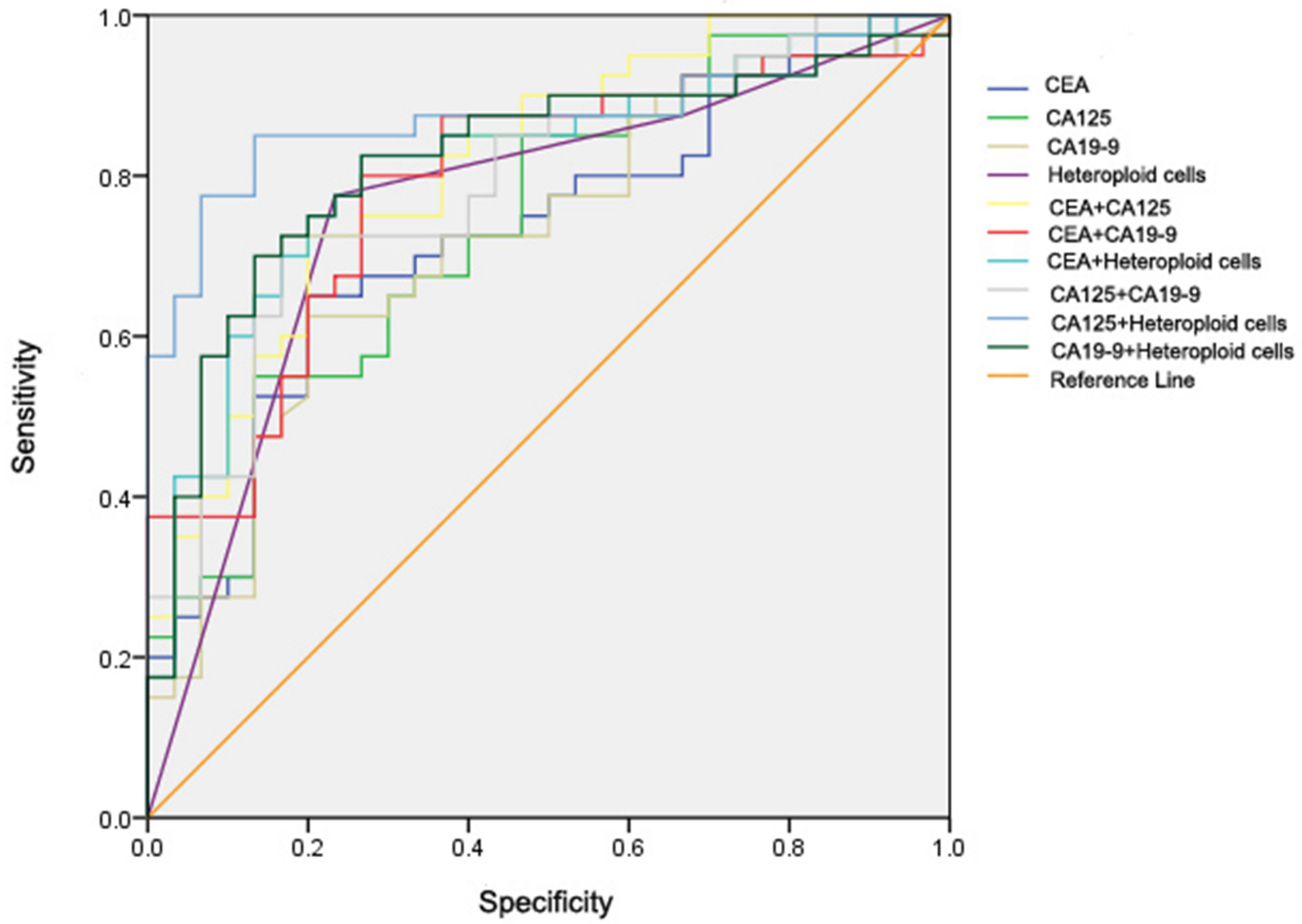

Figure 2 ROC of tumor markers and heteroploid cells in the diagnosis of PC in gastrointestinal cancer patients.

indicators for PC detection (the CA125 level and the number of heteroploid cells) yields a high diagnostic sensitivity and specificity in patients with gastrointestinal and ovarian cancer (75.9\% and $79.5 \%$, respectively) and in those with gastrointestinal cancer $(85.0 \%$ and $86.7 \%$, respectively). Moreover, the highest Youden's index were

Table 8 The Area of ROC of Ascites Tumor Markers and Heteroploid Cells in Gastrointestinal Cancer Patients

\begin{tabular}{|c|c|c|c|}
\hline Category & Area & $\boldsymbol{P}$ & $95 \% \mathrm{Cl}$ \\
\hline $\mathrm{CA} / 25$ & 0.742 & 0.001 & $0.626-0.857$ \\
\hline CEA & 0.723 & 0.001 & $0.604-0.843$ \\
\hline CAI9-9 & 0.718 & 0.002 & $0.597-0.839$ \\
\hline Heteroploid cells & 0.760 & $<0.001$ & $0.643-0.878$ \\
\hline CAI25+Heteroploid cells & 0.873 & $<0.001$ & $0.787-0.960$ \\
\hline CAI25+CEA & 0.813 & $<0.001$ & $0.713-0.912$ \\
\hline CAI25+CA19-9 & 0.792 & $<0.001$ & $0.686-0.897$ \\
\hline CEA+Heteroploid cells & 0.813 & $<0.001$ & $0.711-0.915$ \\
\hline CEA+CA19-9 & 0.788 & $<0.001$ & $0.681-0.896$ \\
\hline CA19-9+Heteroploid cells & 0.819 & $<0.001$ & $0.7|7-0.92|$ \\
\hline
\end{tabular}

also found with the combination of the same indicators in patients with gastrointestinal and ovarian cancer patients at $55.4 \%$, and in those with gastrointestinal cancer at $71.7 \%$.

Based on the above results, ascites tumor markers and heteroploid cells may become valuable markers for the diagnosis of PC. We found that the ascites CA125,

Table 9 Tumor Markers and Heteroploid Cells in the Diagnosis of PC in Gastrointestinal Cancer Patients

\begin{tabular}{|l|l|l|l|}
\hline Category & $\begin{array}{l}\text { Sensitivity } \\
\text { (\%) }\end{array}$ & $\begin{array}{l}\text { Specificity } \\
\text { (\%) }\end{array}$ & $\begin{array}{l}\text { Youden's } \\
\text { Index (\%) }\end{array}$ \\
\hline CAI25 & 55.0 & 86.6 & 41.7 \\
CEA & 65.0 & 80.0 & 45.0 \\
CA19-9 & 62.5 & 80.0 & 42.5 \\
Heteroploid cells & 77.5 & 76.7 & 54.2 \\
CAI25+Heteroploid cells & 85.0 & 86.7 & 71.7 \\
CA125+CEA & 72.5 & 80.0 & 52.5 \\
CA125+CA19-9 & 72.5 & 83.3 & 55.8 \\
CEA+Heteroploid cells & 82.5 & 73.3 & 55.8 \\
CEA+CA19-9 & 80.0 & 73.3 & 53.3 \\
CA19-9+Heteroploid cells & 70.0 & 86.6 & 56.7 \\
\hline
\end{tabular}


CEA, and CA19-9 levels are useful markers for the diagnosis of $\mathrm{PC}$ in patients with gastrointestinal and ovarian cancer. But, the serum CEA, CA19-9, and CA125 levels may not be associated with the occurrence of PC, although several articles have argued that serum tumor marker levels are clinically useful markers predicting the prognosis of patients with peritoneal dissemination. ${ }^{24,25}$ We suspect that enlarging the sample size of this study might produce similar results. Because ascites fluid is in direct contact with primary tumors and large amounts of tumor cells are present in ascites fluid, the detection of tumor marker levels in ascites more may directly and effectively reflect tumor changes than the serum marker levels. ${ }^{26}$ Furthermore, the heteroploid cells in ascites fluid may help diagnose PC. The presence of 3 or more heteroploid cells in the ascites samples could predict the occurrence of PC. In addition, a combination of ascites CA125 level and heteroploid cell presence can increase the sensitivity and specificity of the PC diagnoses.

Compared to peritoneal biopsy and laparoscopy, paracentesis is much easier to carry out in clinical settings to obtain samples for detection with minimum invasion. Furthermore, the cost of paracentesis is far less than the cost of the peritoneal biopsy and laparoscopy. In addition, flow cytometer has much higher detection rate of heteroploid cells in ascites than that of by cytology. In all, our proposed method has such advantages as simple, safe, cost low, easy to operate, and with higher detection rate. Although tumor markers and DNA ploidy analysis in ascites fluid cannot replace pathological and imaging diagnoses, they can help make the PC diagnoses more accurate.

In summary, the ascites levels of CEA, CA125, CA199 and the heteroploid cell analysis results can be considered valuable markers for the diagnosis of $\mathrm{PC}$ in patients with gastrointestinal and ovarian cancer. Moreover, a combination of the ascites CA125 level and the result of the heteroploid cell analysis had the best diagnostic sensitivity and specificity for PC.

\section{Ethics Approval and Consent to Participate}

The IRB of the Tangdu Hospital of Air Force Military Medical University approved this study. All subjects provided written informed consents before the tests. We ensured that the data were anonymized and analyzed maintaining confidentiality.

\section{Funding}

The National Natural Science Foundation of China supported this study (No. 81702847).

\section{Disclosure}

The authors declare that they have no conflicts of interest.

\section{References}

1. Chubb SP, Williams RA. Biochemical Analysis of Pleural Fluid and Ascites. Clin Biochem Rev. 2018;39(2):39-50.

2. Montori G, Coccolini F, Fugazzola P, et al. Cytoreductive surgery and hyperthermic intraperitoneal chemotherapy in ovarian and gastrointestinal peritoneal carcinomatosis: results from a 7-year experience. J Gastrointest Oncol. 2018;9(2):241-253. doi:10.21037/jgo.2017.12.04

3. Lambert LA. Looking up: recent advances in understanding and treating peritoneal carcinomatosis. CA Cancer J Clin. 2015;65 (4):284-298.

4. Klaver YL. Peritoneal carcinomatosis of colorectal origin: incidence, prognosis and treatment options. World j Gastroenterology. 2012;18 (39):5489-5494. doi:10.3748/wjg.v18.i39.5489

5. van Baal J, van Noorden CJF, Nieuwland R, et al. Development of Peritoneal Carcinomatosis in Epithelial Ovarian Cancer: A Review. j Histochemistry Cytochemistry. 2018;66(2):67-83. doi:10.1369/ 0022155417742897

6. Najah H, Lo Dico R, Dohan A, Marry L, Eveno C, Pocard M. A feasibility study of the use of computed virtual chromoendoscopy for laparoscopic evaluation of peritoneal metastases. Surg Endosc. 2017;31(2):743-751. doi:10.1007/s00464-016-5028-1

7. Schmidt S, Meuli RA, Achtari C, Prior JO. Peritoneal carcinomatosis in primary ovarian cancer staging: comparison between MDCT, MRI, and 18F-FDG PET/CT. Clin Nucl Med. 2015;40(5):371-377. doi:10.1097/RLU.0000000000000768

8. Trilling B, Cotte E, Vaudoyer D, et al. Intraperitoneal-Free Cancer Cells Represent a Major Prognostic Factor in Colorectal Peritoneal Carcinomatosis. Dis Colon Rectum. 2016;59(7):615-622. doi:10.1097/DCR.0000000000000589

9. Rodriguez-Enriquez S, Pacheco-Velazquez SC, Gallardo-Perez JC, et al. Multi-biomarker pattern for tumor identification and prognosis. J Cell Biochem. 2011;112(10):2703-2715. doi:10.1002/jcb.23224

10. Kim BC, Bae JH, Park SM, Won DY, Lee IK. Is ascites CEA a risk factor for peritoneal carcinomatosis in colorectal cancer?: a long-term follow-up study. Int $J$ Colorectal Dis. 2020;35(1):147-155. doi:10. 1007/s00384-019-03448-2

11. Sturgeon C. Practice guidelines for tumor marker use in the clinic. Clin Chem. 2002;48(8):1151-1159. doi:10.1093/clinchem/48.8.1151

12. Zhang W, Tong Q, Wang X, Wang Q, Li S. T lymphocyte subsets determination and DNA ploidy analysis in the differential diagnosis between benign and malignant ascites. Cancer Invest. 2009;27(1): 67-69. doi:10.1080/07357900802161062

13. Zaini ZM, McParland H, Møller H, Husband K, Odell EW. Predicting malignant progression in clinically high-risk lesions by DNA ploidy analysis and dysplasia grading. Sci Rep. 2018;8(1):15874. doi:10. 1038/s41598-018-34165-5

14. Gilly FN, Cotte E, Brigand C, et al. Quantitative prognostic indices in peritoneal carcinomatosis. European Journal of Surgical Oncology (EJSO). 2006;32(6):597-601. doi:10.1016/j.ejso.2006.03.002

15. Coccolini F, et al. Peritoneal carcinomatosis. World $j$ Gastroenterology. 2013;19(41):6979-6994. doi:10.3748/wjg.v19.i41.6979

16. Matte I, Lane D, Bachvarov D, Rancourt C, Piche A. Role of malignant ascites on human mesothelial cells and their gene expression profiles. BMC Cancer. 2014;14(1):288. doi:10.1186/1471-2407$14-288$ 
17. Hu Y, Qi C, Liu X, et al. Malignant ascites-derived exosomes promote peritoneal tumor cell dissemination and reveal a distinct miRNA signature in advanced gastric cancer. Cancer Lett. 2019;457:142-150. doi:10.1016/j.canlet.2019.04.034

18. Zheng L-N, Wen F, Xu P, Zhang S. Prognostic significance of malignant ascites in gastric cancer patients with peritoneal metastasis: A systemic review and meta-analysis. World j Clin Cases. 2019;7 (20):3247-3258. doi:10.12998/wjcc.v7.i20.3247

19. Bisht B, Handa U, Mohan H, Lehl SS. Complementary value of DNA flow cytometry and image morphometry in detection of malignant cells in effusion fluids. Malays J Pathol. 2014;36(2):83-90.

20. Ahadi M, Tehranian S, Memar B, et al. Diagnostic value of carcinoembryonic antigen in malignancy-related ascites: systematic review and meta-analysis. Acta Gastroenterol Belg. 2014;77 (4):418-424.

21. Kaleta EJ, Tolan NV, Ness KA, O'Kane D, Algeciras-Schimnich A. CEA, AFP and CA 19-9 analysis in peritoneal fluid to differentiate causes of ascites formation. Clin Biochem. 2013;46(9):814-818. doi:10.1016/j.clinbiochem.2013.02.010
22. Liu F, Kong X, Dou Q, et al. Evaluation of tumor markers for the differential diagnosis of benign and malignant ascites. Ann Hepatol. 2014;13(3):357-363. doi:10.1016/S1665-2681(19)30865-8

23. Kundu R, Handa U, Mohan H. Role of DNA flow cytometry and immunocytochemical analysis in diagnosis of malignant effusions. Diagn Cytopathol. 2012;40(10):887-892. doi:10.1002/dc.21673

24. Emoto S, Ishigami H, Yamashita H, Yamaguchi H, Kaisaki S, Kitayama J. Clinical significance of CA125 and CA72-4 in gastric cancer with peritoneal dissemination. Gastric Cancer. 2012;15 (2):154-161. doi:10.1007/s10120-011-0091-8

25. Wagner PL, Austin F, Sathaiah M, et al. Significance of serum tumor marker levels in peritoneal carcinomatosis of appendiceal origin. Ann Surg Oncol. 2013;20(2):506-514. doi:10.1245/s10434-012-2627-5

26. Liu D, Kong D, Li J, et al. HE4 level in ascites may assess the ovarian cancer chemotherapeutic effect. J Ovarian Res. 2018;11 (1):47. doi:10.1186/s13048-018-0402-3

\section{Publish your work in this journal}

Cancer Management and Research is an international, peer-reviewed open access journal focusing on cancer research and the optimal use of preventative and integrated treatment interventions to achieve improved outcomes, enhanced survival and quality of life for the cancer patient.
The manuscript management system is completely online and includes a very quick and fair peer-review system, which is all easy to use. Visit http://www.dovepress.com/testimonials.php to read real quotes from published authors. 